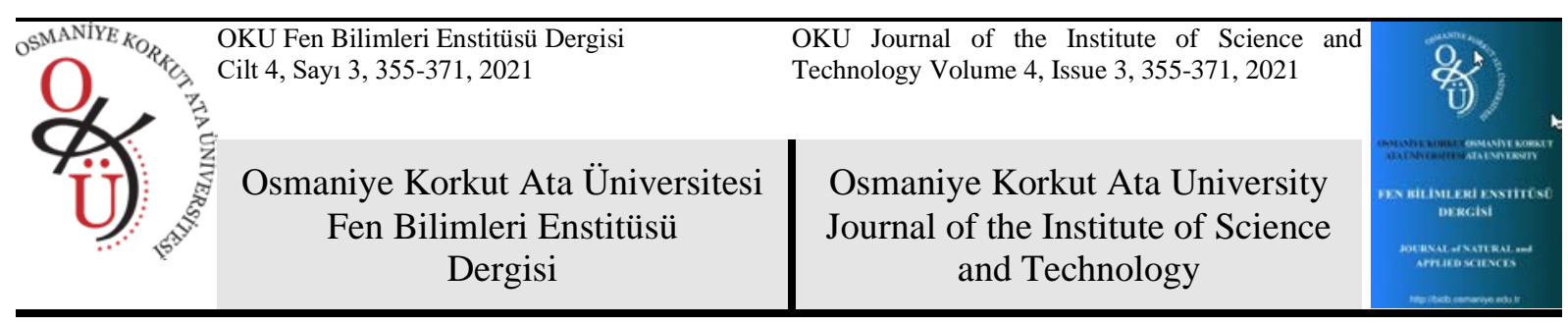

\title{
Diyarbakır’da İlköğretim Öğrencilerinin Hayvansal Kaynaklı Protein Tercih ve Tüketimlerinin Belirlenmesi
}

\author{
Ramazan DEMIREL ${ }^{1}$, Ali Murat TATAR², Dilek Şentürk DEMIIREL ${ }^{3 *}$ \\ 12,3Dicle Üniversitesi, Ziraat Fakültesi, Zootekni Bölümü, 21280, Diyarbakır \\ ${ }^{1}$ https://orcid.org/0000-0003-0816-4125 \\ ${ }^{2}$ https://orcid.org/0000-0002-4993-2779 \\ ${ }^{3}$ https://orcid.org/0000-0003-4142-2632 \\ *Sorumlu yazar: e-mail senturk@dicle.edu.tr
}

\begin{tabular}{|c|c|}
\hline Araştırma Makalesi & ÖZET \\
\hline $\begin{array}{l}\text { Makale Tarihçesi: } \\
\text { Geliş tarihi: } 19.03 .2021 \\
\text { Kabul tarihi: } 11.08 .2021 \\
\text { Online Yayınlanma: } 15.12 .2021\end{array}$ & $\begin{array}{l}\text { Araştırma, Diyarbakır merkeze bağlı } 4 \text { ilçede (Bağlar, Kayapınar, Sur, } \\
\text { Yenişehir) öğrenim gören } 478 \text { ilkögretim ögrencisi ile gerçekleştirilmiştir. } \\
\text { Her bir ilçede önceden belirlenen okullardan, ilköğretim } 4 ., 6 \text {. ve } 7 \text {. sınıf } \\
\text { öğrencileriyle yapılan anketlerden elde edilen veriler kullanılarak bu çalışma } \\
\text { gerçekleştirilmiştir. Anket verileri Khi kare testiyle değerlendirilmiş ve elde } \\
\text { edilen sonuçlar yorumlanmıştır. Yapılan anketlerle, öğrencilerin cinsiyeti, } \\
\text { yaşı, yaşadığ1 ilçe, sınıfı, kardeş sayısı, ailenin eğitim durumu ve } \\
\text { ebeveynlerinin maddi durumları ile beslenme tercihleri, tüketilen et ve et } \\
\text { ürünleri, süt ve süt ürünleri, yumurta tüketimleri arasındaki istatistiksel ilişki } \\
\text { araştırılmıştır. Araştırma sonucuna göre, öğrencilerin cinsiyeti, yaşı, bağlı } \\
\text { olduğu ilçe, sınıf, kardeş sayısı, ailenin eğitim durumu ve ebeveynlerinin } \\
\text { maddi durumu ile hayvansal proteinle beslenme tercihleri arasında istatiksel } \\
\text { olarak farklılık olduğu saptanmıştır. }\end{array}$ \\
\hline
\end{tabular}

Determination of Animal Based Protein Preferences and Consumptions of Primary and Secondary School Students in Diyarbakır

\section{Research Article}

\section{Article History:}

Received: 19.03.2021

Accepted: 11.08.2021

Published online: 15.12.2021

\section{Keywords:}

Animal protein

Fish

Meat

Egg

\begin{abstract}
This research was carried out with 478 primary and middle school students in 4 central districts (Bağlar, Kayapınar, Sur, Yenişehir) of Diyarbakır. This study was carried out using the data obtained from primary of questionnaires with 4th, 6th and 7th grade students from pre-determined schools in each district. The survey data were evaluated with the Khi square test and the results were interpreted. With the surveys, the statistical relationship between students' gender, age, district, class, number of siblings, education status of the family and the financial status of their parents and their nutritional preferences, meat and meat products consumed, milk and dairy products, egg consumption were investigated. According to the results of the research, it was found that there is a statistical relationship between the gender, age, district, class, number of siblings, education level of the family and the financial status of the parents and the preferences of animal protein.
\end{abstract}

To Cite: Demirel R., Tatar AM., Demirel DŞ. Diyarbakır'da İlköğretim Öğrencilerinin Hayvansal Kaynaklı Protein Tercih ve Tüketimlerinin Belirlenmesi. Osmaniye Korkut Ata Üniversitesi Fen Bilimleri Enstitüsü Dergisi 2021; 4(3): 355-371. 


\section{Giriş}

Dünya'da ve ülkemizde son yıllarda hızla artan nüfus, insanların nicel ve nitel olarak beslenme problemlerini daha belirgin hale getirmektedir. Günümüzde özellikle gelişmemiş ülkelerde ciddi ölçüde yetersiz ve dengesiz beslenmeden dolayı sağlık problemleri meydana gelmektedir. Bunun başlıca nedenleri: kuraklık, aşırı yağışlar, hastalık ve zararlılar, tarım arazilerinin insan yerleşimlerine açılması vb. yanı sıra, gelişmiş ülke insanlarının aşırı gıda tüketimleri ve gıda israfıdır. Dünyadaki mevcut gıda kaynakları adil bölüşülmemekte ve önemli bir kısmı da israf edilmektedir. Hızlı nüfus artışı devam ettiği sürece bu dengesizlik ve yetersizlik daha belirgin hale gelecektir.

İnsanın büyüme, gelişme, sağlıklı ve üretken olarak yaşayabilmesi için gerekli olan besin öğelerinin hepsini belirli bir zaman diliminde yeterli miktarlarda alabilmesi gerekmektedir. Bu öğelerin herhangi birinin yetersizliğinde veya gereğinden çok alındığında, büyüme ve gelişmenin engellendiği ve sağlığın bozulduğu bilinmektedir. Vücudun büyüme ve gelişmesi, verimli çalışması, dış etkenlere ve hastalıklara karşı dirençli olabilmesi için yeterli ve dengeli beslenme büyük öneme sahiptir. Yaşamın sağl1klı olarak sürdürülebilmesi için vücudun ihtiyaç duyduğu protein ihtiyacının mutlaka günlük olarak alınması gerekir. Hücrelerde çok az miktarda protein depolanabildiği için ihtiyaçtan fazla alınan protein yağa ve glikojene dönüştürerek depolanmaktadır.

Alınan proteinin kaynağı ve kalitesi de son derece önemlidir. Hayvansal proteinlerin bitkisel proteinlere göre sindirimi kolay ve emilim oranı daha yüksektir. Ayrıca hücrelerin ihtiyaç duyduğu tüm amino asitler hayvansal proteinlerde yeterli miktarlarda bulunur. Boy uzamasına, kan hücrelerinin çoğalmasına, bağışıklık sistemi elemanlarının aktifleşmesine, kas ve sinir sisteminin gelişiminde rol oynayan amino asitler daha çok hayvansal gıdalarda bulunur. Sağlıklı birey ve toplum için özellikle çocukların gelişme dönemlerinde ihtiyaç duyduğu besin öğelerini yeterli ve dengeli olarak alabilmeleri gerekir. Enerji ve besin öğeleri (protein, vitamin ve mineraller vb.) vücudun gereksinmeleri düzeyinde alınamazsa, yeterli enerji oluşmadığı ve vücut dokularının ihtiyaçları karşılanamadığı için yetersiz beslenmeye bağlı sorunlar meydana gelmektedir. Yeterli besin tüketimine karşın, uygun seçim yapılmadığı ya da yanlış pişirme yöntemi uygulandığı zaman bu besinlerin vücut çalışmasındaki işlevi yerine getirilemediğinden yine dengesiz beslenme denilen sağlık problemi oluşmaktadır.

Okul çağındaki çocukların sağlıklı ve dengeli beslenmesi fiziksel gelişmeyi sağladığı gibi, okul başarısını ve ileriki yıllarda kronik hastalıkların önlenmesinde etkilidir. Okul dönemi çocuklarının, sağlıklarının korunarak, büyüme ve gelişmelerinin sürdürebilmesi için yaşlarına uygun olarak beslenmeleri gerekir (Garipağaoğlu ve Güneş, 2008). Kahvaltı yapmadan okula giden çocukların dersleri yeterince anlamadıkları, algılamalarının düşük, dikkat sürelerinin kısa olduğu, öğrenmede güçlük çektikleri, bazılarında da baş dönmesi ve ağrı gibi sorunları olduğu ifade edilmiştir (Baysal. 1999)

Çin’de on yaşındaki kız çocukları iki yıl boyunca düzenli süt tükettikten sonra süt içmeyenlere göre boyları hızla artmış ve kemik yoğunluğu yüksek bulunmuştur (Du ve ark. 2004). 
Türkiye'de bireylerin beslenmesinde günlük alınması gereken enerji düzeyi yeterliyken, dengesiz beslenmenin söz konusu olduğu ifade edilmiştir. Ülkemizde genel olarak, yeterli ve dengeli beslenmeyi sağlayacak miktar ve kalitede hayvansal ürünlere erişim sorunu özellikle kırmızı et konusunda yaşanmaktadır (Gürer, 2013).

Yeterli ve dengeli beslenme, büyüme ve gelişme, varlığın sürdürülebilmesi ve faaliyetlerin en iyi biçimde yapılabilmesi için gerekli besinlerin çeşitlerini uygun miktarlarda, besin değerini yitirmeden, sağlığı bozmadan en ekonomik biçimde alınması ve vücutta kullanılması olarak tanımlanır (Açıkgöz, 2006). Bir ülkenin ekonomik ve sosyal yönden kalkınmasında en önemli etken olan sağlıklı, üretken ve yetenekli insan potansiyeline sahip olabilmek için toplumu oluşturan bireylerin özellikle de sürekli ve hızlı bir büyüme ve gelişme süreci içinde bulunan çocukların yeterli ve dengeli bir şekilde beslenmesi gerekmektedir (Baykan, 1999). Nitekim beslenme anne karnından yaşlılığa kadar insan yaşamında her dönemde önemlidir (Pekşen, 2010) .

Besin gruplarından herhangi biri gereğinden az ya da çok alındığında büyüme ve gelişmenin engellendiği, sağlığın bozulduğu bilimsel olarak ortaya konulmuştur (Baysal, 2004). Beslenmede amaç; bireyin yaşına, cinsiyetine, çalışma ve özel durumuna göre ihtiyacı olan enerji ve besin öğelerinin her birinin yeterli miktarlarda sağlanmasıdır (Kılıç ve Şanlıer, 2007).

Okul çağı çocukların toplumsal yaşamdaki ilk dönemi olması nedeniyle beslenme alışkanlıklarının oluşmasında aile, arkadaş çevresi reklamlar ve okul kantini en büyük etkiye sahip olması nedeniyle de eğitim ve denetlemenin gerekliliği ortadadır (Karaca ve ark. 2007).

Annenin eğitimi ve statüsünün çocukların sağlıklı ve dengeli beslenmelerinde oldukça önemlidir. Okul çağındaki çocukların hızlı bir büyüme ve gelişme süreci içinde olmaları nedeniyle, en yüksek düzeyde besin maddelerine bu dönemde ihtiyaç duymaktadırlar ve bu dönemde kazanılacak beslenme alışkanlıklarının ömür boyu sürdürüldüğü ifade edilmektedir (Törüner, Büyükgönenç, 2012).

Ailelerin yiyecek tercihleri ve alışkanlıklarının çocukların beslenme alışkanlıkları ve yiyecek seçimlerini etkilemesi nedeniyle sağlıklı ve dengeli beslenme konusunda ailelerin bilgilenmesinin büyük önemi bulunmaktadır (Bilgen Sivri ve Özpulat 2015).

$\mathrm{Bu}$ çalışmada, Diyarbakır merkeze bağlı 4 ilçede bulunan ilköğretim öğrencilerinin kardeş sayısı, ekonomik durum, ailelerin eğitim durumu vb. faktörlere göre çocukların beslenme durumları, hayvansal protein kaynaklarına karşı ilgileri ve hayvansal protein kaynağı tercihlerinin neler olduğunun belirlenmesi amaçlanmıştır.

\section{Materyal ve Metot}

Araştırma materyalini 2019 yılı içerisinde Diyarbakır Merkeze bağlı dört ilçede (Bağlar, Kayapınar, Sur, Yenişehir) öğrenim gören 478 ilköğretim (ilkokul ve ortaokul 4, 6 ve 7. sınıf) öğrencisiyle yapılan anketlerden elde edilen veriler oluşturmuştur. 
İlçedeki okullar ailelerin gelir durumu ve nüfus yoğunluğu göz önüne alınarak belirlenmiştir. Okul idaresinden anket için gerekli izinler şifahi olarak alındıktan sonra, daha önce araştırıcılar tarafından hazırlanan ve basılan toplam 29 soru içeren anket formu (Ek1), ders bitiminde öğretmenlerin gözetiminde öğrencilere konu hakkında bilgilendirme yapılarak, her bir öğrenciye ayrı ayrı dağıtılmış ve yaklaşık 15 dakikalık teneffüs süresi içerisinde tamamlanmıştır. Ankette öğrencilerin cinsiyeti, yaşı, yaşadığı ilçe, kardeş sayısı, ailenin eğitim durumu ve ebeveynlerinin maddi durumları, beslenme tercihleri, tüketilen et ve et ürünleri, süt ve süt ürünleri ile yumurta tüketimleri hakkında bilgi edinilmeye çalışılmıştır. Günlük veya haftalık tüketilen hayvansal gıdaların belirlenen porsiyonları üzerinden günlük protein tüketimleri saptanmıştır. Daha sonra hayvansal protein kaynaklarının içerdiği protein oranları, tüketilen protein kaynaklarının miktarlarıyla çarpılarak günlük protein tüketimleri hesaplanmıştır. Bulunan günlük hayvansal protein miktarları bakımından okulunun bulunduğu ilçe (bu aynı zamanda yaşadığı yer olarak da kabul edilmiştir), ebeveynlerin maddi durumları (öğrencilerin günlük harçlık miktarlarına göre kabul edilmiştir), kardeş sayıları vb. özellikler arasında kıyaslamalar yapılmıştır.

Araştırma verileri SPSS 21.0 paket programıyla, istatistiksel analizler Khi kare yöntemine göre değerlendirilmiş, gruplar arasındaki farklılığın belirlenmesinde Duncan çoklu karşılaştırma testi kullanılmıştır.

\section{Öğrencilerin yaş gruplarına göre tüketmeleri gereken protein kaynağı porsiyon miktarları}

Süt grubundan yaş gruplarına göre bir günde tüketilmesi önerilen porsiyon miktarları;

5 - 11 yaş grubu çocuklarda 2,5 - 3 porsiyon;

12 - 18 yaş grubu çocuklarda 3 porsiyon

\section{Bir porsiyona eş değer süt grubu besinlerin miktarlar}

Süt, yoğurt, kefir: $200 \mathrm{ml}$;

Ayran: $350 \mathrm{ml}$;

Beyaz peynir türleri: 60 g;

Kaşar peynir türleri: $40 \mathrm{~g}$;

Yaş çökelek - lor peyniri: $150 \mathrm{~g}$

Et, yumurta grubundan yaş gruplarına göre bir günde tüketilmesi önerilen porsiyon miktarları 5 - 11 yaş grubu çocuklarda: 2 - 3 porsiyon;

12 - 18 yaş grubu çocuklarda: 2,5 - 4 porsiyon,

Bir porsiyona eş değer et ve yumurta grubu besinlerin miktarları:

Et çeşitleri (kırmızı, tavuk, hindi vb): $100 \mathrm{~g}$;

Balık: $150 \mathrm{~g}$;

Yumurta: 100 g (2 adet) (Anonim, 2020a)

\section{Hayvansal ürünlerin protein içerikleri (\%)}

\section{A. Süt ve Ürünleri:}

İnek sütü: 3,4

İnek yoğurdu: 3,5 
Beyaz peynir: 19

Örgü peyniri: 27

Kaşar peyniri: 27

Otlu peynir: 15

\section{B. Etler:}

Dana eti: 18

Koyun, keçi eti: 18

Tavuk, hindi eti: 21

Balık eti: 20

\section{Yumurta:}

Tüm yumurta: 12 (Anonim, 2020b)

Öğrencilerin yaş gruplarına göre tüketmeleri önerilen günlük protein kaynağı porsiyon ve miktarları Hacettepe Üniversitesi yayını “Türkiye’ye Özgü Besin ve Beslenme Rehberi”nden alınırken (Anonim 2020a), hayvansal ürünlerin protein içerikleri Sağlık Bakanlığı'nın Türkiye Beslenme Rehberinden alınmıştır (Anonim 2020b).

\section{Bulgular ve Tartışma}

Ankete 229 (\%47,91) kız ve 249 (\%52,09) erkek öğrenci katılmıştır. Kızların ortalama kilosu 38,24 kg iken, erkeklerin kilosu 38,78 kg olarak tespit edilmiştir. Ankete katılan öğrencilerin \%94,56'sının günlük harçlık aldığı, \%5,44'ünün ise almadığı tespit edilmiştir. Öğrenci ailelerinin \%33,26'sının kiralık evde, \%66,74'ünün ise kendi evlerinde ikamet ettikleri belirlenmiştir. Ailelerin \%42,26'sının otomobil sahibi oldukları, \%57,74'ünün ise otomobil sahibi olmadığı belirlenmiştir. Hiç kardeşi olmayan sadece $3(\% 0,63)$ öğrenci bulunurken, kardeş sayısı 1-3 arası olan $216(\% 45,19), 4-6$ arası 199 (\%41,63), 7-9 aras1 55 (\%11,51) ve >10 olan 5 (\%1,05) öğrenci tespit edilmiştir.

\section{İlköğretim Öğrencilerinin Günlük Protein Tüketimi}

Öğrencilerle yüz yüze gerçekleştirilen anket sonucunda (478 öğrenciyle) elde edilen verilere göre; erkek öğrencilerin (229 kişi) ortalama günlük protein tüketimi 35,16 g iken, kız öğrencilerin (249 kişi) 33,82 g olarak belirlenmiştir. Erkek öğrencilerin ortalama canlı ağırlıkları 38,24 kg, kız öğrencilerin ise $38,78 \mathrm{~kg}$ olarak tespit edilmiştir (Tablo 1). Öğrencilerin canlı ağırlıkları dikkate alındığında her iki cinsiyetinde yeterli miktarda günlük protein aldıkları söylenebilir. Zira sağlıklı ve dengeli beslenmek için günlük protein tüketimi kg ağılık başına en az 0,8-1 g olması gerekir (Anonim 2020b). Bu değer gelişme çağındaki çocukların fiziksel ve mental gelişimleri içinde oldukça önemlidir. Ankete katılan öğrencilerin günlük hayvansal protein tüketimi içinde en büyük payı süt ve süt ürünleri alırken, bunu sırasıyla tavuk, balık ve kırmızı et izlemiştir. Öğrencilerin tükettikleri toplam proteindeki en büyük payı \%24,6 ile peynir oluştururken, et çeşitlerinden \%20,6'lık payla tavuk, daha sonra balık ve kırmızı et takip etmiştir. Benzer sonuçlar Kutlu ve Çivi (2009) tarafından 7 - 14 yaşlarındaki öğrencilerin 
günlük hayvansal protein kaynağı tüketimlerinin büyük ölçüde süt ve ürünlerinden karşılandığını bildiren çalışmalarıyla uyumlu iken, et tercihleri ve tüketim miktarlarıyla uyumlu bulunmamıştır.

\section{İlçelere Göre Öğrencilerin Günlük Protein Tüketimi}

Yenişehir ilçesinde ikamet eden öğrencilerin en düşük kiloya sahip olmalarına rağmen, toplam protein tüketimi (37,16 g) diğer ilçelere göre daha yüksek bulunmuştur. Okul çağındaki çocukların sağlıklı ve dengeli beslenmeleri açısından bu sonuç olumlu görülmektedir. Günlük toplam protein tüketimi açısından Yenişehir ilçesini sırasıyla Sur (36,28 g), Kayapınar (33,51 g) ve Bağlar (32,20 g) ilçelerinin izlediği tespit edilmiştir. Tüketilen et çeşitlerinden protein ihtiyaçlarının büyük bir kısmını tavuk etinden karşılandığı, fakat Sur ilçesinde balığın, tavuk etinden daha çok tüketildiği belirlenmiştir (Tablo 1, Şekil 1). İlçelerde yaşayanların gelir durumları dikkate alındığında, en düşük gelire sahip olanların yaşadığı Bağlar ilçesindeki öğrencilerin daha az günlük protein tükettikleri belirlenmiştir.

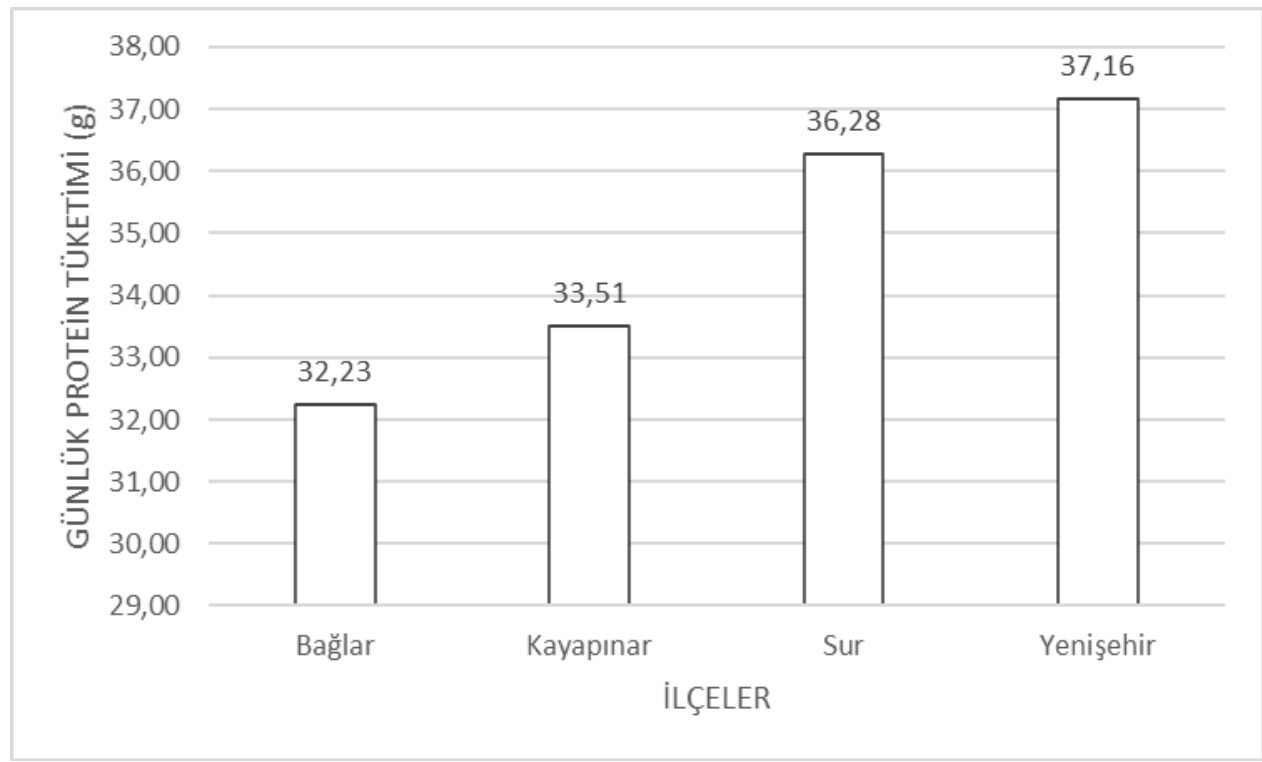

Şekil 1. Öğrencilerin Yaşadıkları İlçelere Göre Günlük Protein Tüketimleri (g)

\section{Öğrencilerin Sınıflara Göre Günlük Protein Tüketimi}

Araştırma sonucunda elde edilen sonuçlara göre 4. ve 6. sınıflardaki öğrencilerin protein tüketimleri arasında istatistiki olarak önemli düzeyde farklılık bulunmazken, 7. sınıf öğrencileriyle karşılaştırıldığında önemli $(\mathrm{P}<0,05)$ bulunmuştur. Ortalama en yüksek protein tüketimi 37,16 g ile 4 'üncü sınıf öğrencilerinde saptanırken, bunu 36,24 g ile 6. sınıf ve 33,05 g ile 7. Sınıf öğrencileri izlemiştir. Öğrencinin sınıfı ve yaşı arttıkça kilosunun da arttığı dikkate alındığında protein tüketiminin de doğru orantılı olarak artması beklenmektedir. Oysa çalışmamızdan elde edilen sonuca göre öğrencinin sınıfı ve yaşı arttıkça protein tüketiminin azaldığı tespit edilmiştir. Bunun muhtemel nedenlerinin başında öğrencinin yaşı ilerledikçe ebeveynlerin çocuklarının besin tüketimi üzerine etkisinin azalması gelmektedir. Öğrencinin sınıf düzeyi yükseldikçe en yüksek hayvansal protein 
tüketiminin artarak peynirden sağlandığı, bunu sırasıyla, tavuk, balık ve kırmızı etin izlediği tespit edilmiştir (Tablo 1, Şekil 2).

\section{Yaş Gruplarına Göre Öğrencilerin Günlük Protein Tüketimleri}

Yaş gruplarına göre günlük toplam protein tüketimi değerleri arasındaki farklılık istatistiksel olarak önemli bulunmuştur $(\mathrm{P}<0,01)$. Öğrencilerin yaşa bağlı protein tüketimi en çok 10 yaşında $(37,55 \mathrm{~g})$, en az protein tüketimi ise 14 yaşında olan çocuklarda $(28,89 \mathrm{~g})$ görülmüştür. En küçük yaş grubu olan 9 yaşındaki öğrenciler hariç, yaş arttıkça protein tüketiminin azaldığı tespit edilmiştir. Öğrencinin yaşı arttıkça süt ve peynir tüketimi azalırken, balık ve tavuk eti tüketiminin arttığ 1 tespit edilmiştir. En çok peynir tüketenlerin 9 yaşında, sütü 10 yaşındaki çocukların diğer yaşlardaki çocuklardan daha çok tükettiği, yoğurdu daha çok 14 yaşındakilerin tükettikleri, balık, tavuk ve kırmızı eti 14 yaşındaki çocukların çoğunlukta tükettiği tespit edilmiştir (Tablo 1). Bunun nedeni de öğrenci büyüdükçe ebeveynlerinin baskısının etkisinin azalması olduğu düşünülmektedir. Öğrencilerin kiloları ile tükettikleri günlük toplam protein miktarı dikkate alındığında sağlıklı ve dengeli beslenme için gereken protein tüketiminin yeterli olması nedeniyle beslenme açısından endişelenilecek bir durumun olmadığını söylemek mümkündür. Başka bir deyişle ankete katılan çeşitli yaş grubundaki öğrencilerin dengeli beslendiği söylenebilir. Araştırma bulgularımız Kutlu ve Çivi’nin (2009) öğrencilerin büyük çoğunluğunun \%62,5'inin süt ve yoğurdu, \%58,9'unun ise peyniri her gün tükettiklerini bildirdikleri çalışmalarıyla benzer bulunmuştur.

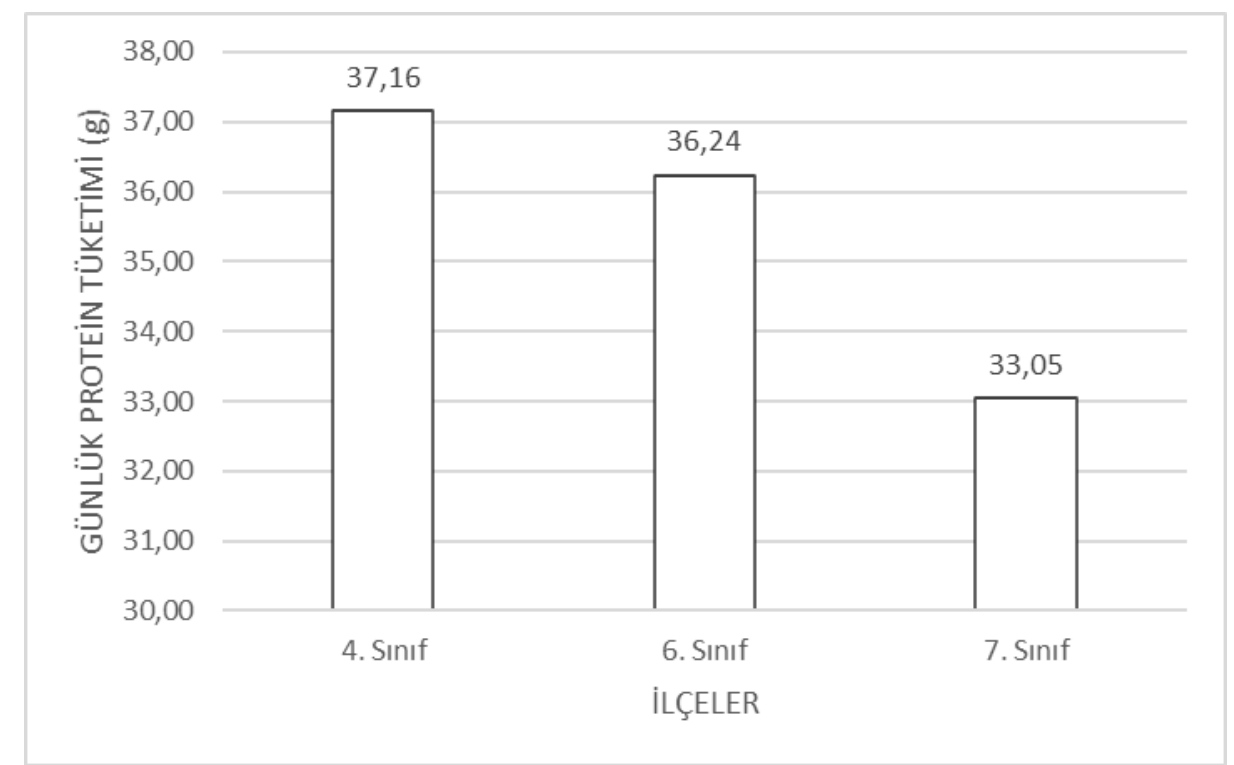

Şekil 2. Öğrencilerin Sınıflara Göre Günlük Protein Tüketimi (g)

\section{Öğrencilerin Kardeş Sayısına Göre Protein Tüketimleri}

Diyarbakır genelde Türkiye, özelde Güneydoğu Anadolu bölgesinde kardeş sayısı yüksek illerden birisidir. Kardeş sayısına göre günlük toplam protein tüketimi değerleri arasındaki farklılık istatistiksel olarak önemsiz bulunurken, canlı ağırlık bakımından önemli $(\mathrm{P}<0,05)$ bulunmuştur. Hiç kardeşi 
olmayanların canlı ağırlı̆̆ kardeşi olanlardan düşük bulunmuştur. Bunu hiç kardeşi olmayanların sayısının azlığıyla açıklamak mümkündür. Anket sonuçlarına göre 219 kişinin en fazla 3 kardeşi olduğu, buna karşın 259 kişinin ise 3 ten fazla kardeşe sahip oldukları tespit edilmiştir. Hiç kardeşi olmayanlar ile kardeş sayısı $\geq 10$ olan öğrenciler hariç, genel olarak kardeş sayısı arttıkça protein tüketiminin azaldığı tespit edilmiştir. En yüksek günlük toplam protein tüketimi 37,14 g ile kardeş sayısı 10'dan fazla olan 5 öğrenciyle elde edilirken, en düşük değer 31,89 g ile kardeş sayısı 7 - 9 arasındaki 55 öğrenciyle elde edilmiştir. Hiç kardeşi olmayan 3 öğrencinin günlük protein tüketiminin en büyük kısmını $(\% 26,70)$ balıktan sağlarken; kardeş sayısı 1-3, 4-6 ve $\geq 10$ olan öğrencilerde sırasıyla \%24,12, \%25,70 ve \%23,59 ile peynirden; kardeş sayısı 7-9 arasındaki öğrencinin ise tavuk etinden $(\% 23,56)$ sağladığı belirlenmiştir (Tablo 1, Şekil 3).

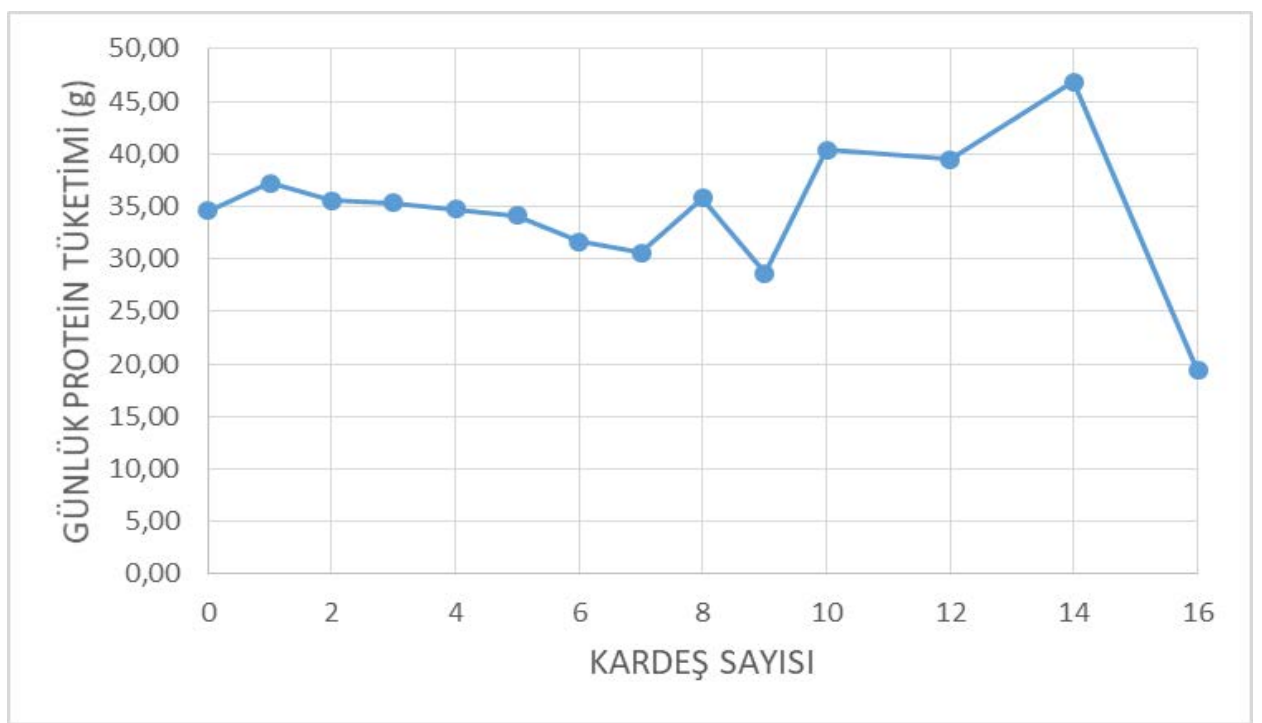

Şekil 3. Öğrencilerin Kardeş Sayısına Göre Protein Tüketimleri (g)

\section{Öğrencilerin Vücut Kitle İndeksine Göre Protein Tüketimleri}

Dünya Sağlık Örgütüne göre (DSÖ) vücut kitle indeksi (VKİ), bireyin canlı ağırlığının boyunun karesine bölümüyle hesaplanır. Buna göre DSÖ çocuklarda VKİ değeri $18,5 \mathrm{~kg} / \mathrm{m}^{2}$ 'in altındaysa zayıf, $18,5-24,9 \mathrm{~kg} / \mathrm{m}^{2}$ arasinda ise normal kilolu, $25-29,9 \mathrm{~kg} / \mathrm{m}^{2}$ arasinda ise fazla kilolu, $30-34,9 \mathrm{~kg} / \mathrm{m}^{2}$ arasında ise 1 . derece obez, $35-39,9 \mathrm{~kg} / \mathrm{m}^{2}$ arasında ise 2 . derece obez, $40 \mathrm{~kg} / \mathrm{m}^{2}$ in üzerinde ise 3 . derece morbid obez olarak tanımlamaktadır (Anonim 2020c).

Vücut kitle indeksi ve öğrencilerin kiloları arasında istatistiksel olarak anlamlı bir farlılık bulunmuştur $(\mathrm{P}<0,01)$. Araştırmada öğrencilerin VKİ bakımından \%32,2'sinin normal kilolu, \%67,8'inin ise zayıf kategoride oldukları görülmüştür. Her iki gruptaki öğrencilerin toplam hayvansal protein tüketimleri benzer bulunmuştur. İlçeler açısından bakıldığında normal kilolu öğrencilerin \%41,6'sı ve zayıf olan öğrencilerin \%42'si Kayapınar ilçesinde yer almaktadır. Cinsiyet bakımından VKİ değerlendirildiğinde normal ve zayıf kilolu kategorilerinde öğrencilerin sırasıyla \%51,3’ünü ve \%52,5’ini kız öğrenciler oluşturmaktadır (Tablo 1). 
Araştırmada elde edilen VKİ değerleri, Taşdemir (2019)'in Şereflikoçhisar'daki 9-12 yaş aralığındaki ilköğretim öğrencilerinin VKI’nin 17,7-17,8 arasında değiştiğini belirttiği sonuçlarla uyumlu bulunurken; Kutlu ve Çivi (2009)'nin yaşları 7-14 arasındaki öğrencilerin fazla kilolu ve obez olanların, zayıf olanlardan daha fazla olduğunu belirttikleri çalışmalarıyla; Kaşıkçı (2010)'un 12-14 yaşlarındaki öğrencilerin \%45,7’sinin VKI normal ve \%43,7'sinin ise zayıf olduğunu bildirdiği sonuçlarla ve Nişancı Kılınç ve Çağdaş (2012)'nın sağlık meslek lisesindeki kız öğrencilerin \%13,9 düzeyinde kilolu ve şişman olduklarını belirttikleri bulgularla uyumlu bulunmamıştır.

\section{Öğrencilerin Harçlık Durumuna Göre Protein Tüketimleri}

Anket yapılan öğrencilerin \%94,56'sının düzenli olarak harçlık aldığı belirlenmiştir. Harçlık alanların günlük protein tüketimi 34,79 g, almayanların ise 28,67 g olup istatistiki olarak önemli bulunmuştur $(\mathrm{P}<0,01)$. Harçlık alan ve almayan öğrencilerin kiloları arasındaki farklılık istatistiki olarak önemsiz bulunmuştur. Harçlık alan öğrencilerin günlük tükettikleri protein miktarının \%60’tan fazlasını peynir, balık ve tavuk etinin oluşturduğu görülmektedir (Tablo 1). Harçlık aldığını ifade eden öğrencilerin süt ve peynir hariç diğer protein kaynaklarını harçlık almayan öğrencilere göre daha az tükettikleri görülmektedir. Bu durum parası olan öğrencilerin evde ailelerinin zorlamasından kurtularak okulda istediklerini satın aldıklarını düşündürmektedir. Düzenli harçlık alamayan, gelir durumu düşük olan çocukların ise yumurta, yoğurt ve tavuk eti gibi nispeten daha ucuz olan kaynaklara yöneldiği söylenebilir.

Aldığ 1 harçlık miktarına göre bakıldığında 1-5 TL harçlık alanlarda yumurta tüketimi, 5 TL den fazla harçlık alanlarda peynir tüketimi, harçlık almayanlarda süt, peynir, balık ve kırmızı et tüketiminin daha çok olduğu tespit edilmiştir. 
Tablo 1. Öğrencilerin Çeşitli Parametrelere Göre Protein Kaynă̆ı Tercihleri ve Günlük Protein Tüketimleri

\begin{tabular}{|c|c|c|c|c|c|c|c|c|c|c|c|c|c|c|}
\hline \multirow[t]{2}{*}{ ÖZELLİK } & & \multirow[t]{2}{*}{$\mathbf{N}$} & \multirow[t]{2}{*}{$\%$} & \multirow{2}{*}{$\begin{array}{l}\text { Öğrenci Kilosu } \\
\bar{X} \pm S_{X}\end{array}$} & \multirow[t]{2}{*}{$\begin{array}{c}\text { En } \\
\text { Küçük }\end{array}$} & \multirow[t]{2}{*}{$\begin{array}{c}\text { En } \\
\text { Büyük }\end{array}$} & \multirow[t]{2}{*}{ Yumurta } & \multirow[t]{2}{*}{ Süt } & \multirow[t]{2}{*}{ Yoğurt } & \multirow{2}{*}{$\begin{array}{c}\text { Peynir } \\
\%\end{array}$} & \multirow[t]{2}{*}{ Balık } & \multirow[t]{2}{*}{ Tavuk } & \multirow[t]{2}{*}{ Kırmızı et } & \multirow[t]{2}{*}{$\begin{array}{c}\text { Günlük } \\
\text { Protein } \\
\text { Tüketimi, g }\end{array}$} \\
\hline & & & & & & & & & & & & & & \\
\hline Öğrencinin & Erkek & 229 & 47,91 & $38,24 \pm 0,444$ & 25 & 62 & 8,12 & 8,73 & 3,86 & 24,61 & 19,28 & 20,48 & 14,91 & 35,16 \\
\hline Cinsiyeti & $\mathrm{K} 1 \mathrm{z}$ & 249 & 52,09 & $38,78 \pm 0,440$ & 25 & 62 & 8,09 & 8,40 & 3,81 & 24,60 & 19,05 & 20,71 & 15,34 & 33,82 \\
\hline \multirow{4}{*}{ İlçe } & Bağlar & 97 & 20,29 & $39,32 \pm 0,635 a$ & 30 & 62 & $9,39 a$ & $6,74 b$ & $4,21 a$ & 23,73ab & 20,17 & $21,68 a$ & $14,09 \mathrm{~b}$ & $32,20 b$ \\
\hline & Kayapınar & 200 & 41,84 & $40,63 \pm 0,451 \mathrm{a}$ & 26 & 60 & $7,81 \mathrm{~b}$ & 6,96b & $3,98 a$ & 25,86a & 18,87 & $21,06 a$ & $15,47 \mathrm{ab}$ & $33,51 b$ \\
\hline & Sur & 90 & 18,83 & $39,47 \pm 0,724 a$ & 27 & 62 & $7,32 b$ & $10,55 a$ & $3,43 b$ & $24,55 a b$ & 19,19 & $19,01 \mathrm{~b}$ & $15,94 a$ & $36,28 a$ \\
\hline & Yenişehir & 91 & 19,04 & $32,12 \pm 0,434 b$ & 25 & 42 & $8,17 b$ & $12,05 a$ & $3,51 b$ & $22,85 b$ & 18,68 & 20,01ab & 14,74ab & $37,16 a$ \\
\hline \multirow{3}{*}{ Sinıfi } & 4 & 91 & 19,04 & $32,12 \pm 0,434^{b}$ & 25 & 42 & $8,17^{\mathrm{ab}}$ & $12,05 a$ & $3,51 b$ & 22,85 & 18,68 & 20,01ab & 14,74 & $37,16 a$ \\
\hline & 6 & 94 & 19,67 & $39,20 \pm 0,709 a$ & 26 & 62 & $7,34^{\mathrm{b}}$ & $10,20 b$ & $3,48 b$ & 24,68 & 19,37 & 19,10b & 15,83 & $36,24 a$ \\
\hline & 7 & 293 & 61,30 & $40,29 \pm 0,370 a$ & 28 & 62 & $8,34^{\mathrm{a}}$ & $6,95 c$ & $4,05 a$ & 25,13 & 19,24 & $21,26 a$ & 15,04 & $33,05 b$ \\
\hline \multirow{6}{*}{ Yaşı } & 9 & 5 & 1,05 & $36,00 \pm 1,975 b$ & 30 & 42 & $7,25 b$ & 10,54ab & $3,56 a$ & $27,54 a$ & 17,74 & $18,29 b$ & 15,07 & $33,14 a b$ \\
\hline & 10 & 69 & 14,44 & $32,17 \pm 0,497 \mathrm{c}$ & 25 & 42 & $8,06 b$ & 11,93a & $3,43 a$ & 23,04ab & 18,99 & $19,56 b$ & 14,99 & $37,55 a$ \\
\hline & 11 & 60 & 12,55 & $36,3 \pm 0,870 b$ & 25 & 50 & $8 \mathrm{~b}$ & 10,32ab & $3,5 a$ & $24,26 a b$ & 18,84 & $19,51 b$ & 15,56 & $35,54 a$ \\
\hline & 12 & 156 & 32,64 & $39,82 \pm 0,533 a b$ & 28 & 62 & $7,88 \mathrm{~b}$ & $8,25 a b c$ & 3,93ab & 25,18ab & 19,32 & $20,55 b$ & 14,88 & $34,48 a b$ \\
\hline & 13 & 169 & 35,36 & $40,34 \pm 0,486 a$ & 28 & 62 & $8,15 b$ & $7,18 b c$ & 3,94ab & $25,44 a$ & 19,16 & $20,91 b$ & 15,23 & $33,47 a b$ \\
\hline & 14 & 19 & 3,97 & $42,47 \pm 1,349 a$ & 32 & 53 & $10,35 a$ & $5,05 c$ & $4,67 a$ & $18,48 b$ & 19,78 & $26,02 a$ & 15,64 & $28,89 b$ \\
\hline \multirow{5}{*}{ Kardeş sayısı } & 0 & 3 & 0,63 & $31,67 \pm 2,963^{\mathrm{b}}$ & 26 & 36 & 8,59 & 13,21 & 3,54 & 19,27 & $26,70^{\mathrm{a}}$ & 17,99 & 10,69 & 34,56 \\
\hline & $1-3$ & 216 & 45,19 & $38,44 \pm 0,475^{a}$ & 25 & 62 & 7,97 & 9,42 & 3,70 & 24,12 & $18,67^{\mathrm{ab}}$ & 20,42 & 15,72 & 35,68 \\
\hline & $4-6$ & 199 & 41,63 & $38,52 \pm 0,448^{a}$ & 25 & 62 & 8,16 & 7,80 & 3,91 & 25,70 & $19,48^{\mathrm{ab}}$ & 20,01 & 14,93 & 33,78 \\
\hline & $7-9$ & 55 & 11,51 & $38,93 \pm 1,030^{\text {a }}$ & 27 & 60 & 8,39 & 7,66 & 4,10 & 22,93 & $19,60^{\mathrm{ab}}$ & 23,56 & 13,76 & 31,89 \\
\hline & $\geq 10$ & 5 & 1,05 & $41,80 \pm 5,083^{a}$ & 30 & 55 & 8,71 & 9,06 & 3,70 & 23,59 & $18,10^{\mathrm{b}}$ & 20,58 & 16,26 & 37,14 \\
\hline \multirow{2}{*}{ VKİ } & Sağllklı Kilo & 154 & 32,22 & $43,92 \pm 0,496^{\mathrm{a}}$ & 30 & 62 & 7,89 & 8,79 & 3,86 & 24,27 & 18,76 & 20,94 & 15,49 & 34,51 \\
\hline & Zayif & 324 & 67,78 & $35,96 \pm 0,308^{b}$ & 25 & 60 & 8,21 & 8,45 & 3,82 & 24,77 & 19,35 & 20,44 & 14,97 & 34,44 \\
\hline \multirow{2}{*}{$\begin{array}{l}\text { Harçlık alma } \\
\text { durumu }\end{array}$} & Evet & 452 & 94,56 & $38,41 \pm 0,314$ & 25 & 62 & $8,01 b$ & $8,74 a$ & 3,80 & 24,86a & 19,09 & $20,37 b$ & 15,12 & $34,79 a$ \\
\hline & Hayır & 26 & 5,44 & $40,46 \pm 1,793$ & 26 & 62 & $9,88 \mathrm{a}$ & $5,34 b$ & 4,35 & $20,17 b$ & 20,33 & $24,51 \mathrm{a}$ & 15,41 & $28,67 b$ \\
\hline \multirow{4}{*}{$\begin{array}{c}\text { Günlük Harçlık } \\
\text { Miktarı }\end{array}$} & $<1 \mathrm{TL}$ & 135 & 28,24 & $38,97 \pm 0,601$ & 25 & 58 & 7,66ab & 9,08 & 3,88 & 25,31 & 18,01 & $20,58 a$ & 15,46 & $35,41 \mathrm{ab}$ \\
\hline & 1-5 TL & 291 & 60,88 & $38,15 \pm 0,399$ & 25 & 62 & $8,46 a$ & 8,29 & 3,87 & 23,91 & 19,55 & $20,95 a$ & 14,97 & $33,67 b$ \\
\hline & $\geq 5 \mathrm{TL}$ & 27 & 5,65 & $38,89 \pm 1,349$ & 30 & 55 & $7,17 b$ & 7,68 & 3,35 & 28,41 & 19,40 & 19,96a & 14,03 & $34,67 a b$ \\
\hline & Almiyor & 25 & 5,23 & $40,08 \pm 1,274$ & 31 & 62 & 7,46ab & 9,79 & 3,67 & 24,73 & 20,57 & $17,25 b$ & 16,53 & 38,33a \\
\hline
\end{tabular}


Tablo 2. Öğrencilerin Ebeveynlerinin Öğrenim Durumu, Mesleği ve Ekonomik Durumlarına Göre Protein Kaynağı Tercihleri

\begin{tabular}{|c|c|c|c|c|c|c|c|c|c|c|c|c|c|c|}
\hline \multirow{2}{*}{ Özellik } & & \multirow{2}{*}{$\mathbf{N}$} & \multirow{2}{*}{$\%$} & \multirow{2}{*}{$\begin{array}{l}\text { Ortalama } \\
\text { Ăğırlık }\end{array}$} & \multirow{2}{*}{$\begin{array}{c}\text { En } \\
\text { Kü̧̈ük }\end{array}$} & \multirow{2}{*}{$\begin{array}{c}\text { En } \\
\text { Büyük }\end{array}$} & Yumurta & Süt & Yoğurt & Peynir & Balık & Tavuk & Kurmızı et & \multirow{2}{*}{$\begin{array}{c}\text { Günlük } \\
\text { Protein } \\
\text { Tüketimi, g }\end{array}$} \\
\hline & & & & & & & & & & $\%$ & & & & \\
\hline \multirow{6}{*}{$\begin{array}{c}\text { Babasının Öğrenim } \\
\text { Durumu }\end{array}$} & Okur Yazar Değil & 21 & 4,39 & $33,05 \pm 0,984 b$ & 27 & 43 & 8,67 & 9,85ab & $4,11 \mathrm{a}$ & 21,07 & 19,65 & $23,59 a$ & $13,06 \mathrm{~b}$ & 34,63 \\
\hline & Okur Yazar & 35 & 7,32 & $34,69 \pm 1,046 b$ & 25 & 52 & 8,09 & $11,93 a$ & $3,43 b$ & 25,00 & 18,66 & $18,77 b$ & 14,12ab & 35,48 \\
\hline & İlkokul & 86 & 17,99 & $39,08 \pm 0,640 \mathrm{a}$ & 25 & 55 & 8,29 & $7,87 \mathrm{bc}$ & $4,18 a$ & 24,43 & 19,73 & $20,54 b$ & 14,95ab & 33,06 \\
\hline & Ortaokul & 106 & 22,18 & $38,88 \pm 0,681 a$ & 26 & 62 & 8,64 & $7,36 \mathrm{c}$ & 3,92ab & 25,04 & 19,66 & $21,07 \mathrm{~b}$ & 14,31ab & 33,28 \\
\hline & Lise & 117 & 24,48 & $38,97 \pm 0,633 a$ & 27 & 54 & 8,22 & $8,27 \mathrm{bc}$ & $3,77 a b$ & 24,77 & 18,47 & $20,79 b$ & $15,72 a$ & 34,33 \\
\hline & Üniversite & 113 & 23,64 & $39,50 \pm 0,672 a$ & 25 & 62 & 7,25 & $9,22 \mathrm{bc}$ & 3,63ab & 24,70 & 19,03 & $20,01 b$ & $16,16 \mathrm{a}$ & 36,43 \\
\hline \multirow{4}{*}{ Babasının Mesleği } & Çiftçi & 6 & 1,26 & $40,00 \pm 4,235^{\mathrm{ab}}$ & 25 & 54 & 7,43ab & 11,09 & $2,91 b$ & 24,44 & 21,51 & $16,39 b$ & 16,23 & $36,08 a b$ \\
\hline & Memur & 134 & 28,03 & $39,29 \pm 0,596^{\mathrm{ab}}$ & 25 & 58 & $7,16 b$ & 9,21 & $3,77 a b$ & 25,07 & 18,33 & 20,49ab & 15,96 & $36,19 a$ \\
\hline & İşçi & 272 & 56,90 & $37,63 \pm 0,408^{b}$ & 25 & 62 & $8,56 a$ & 8,20 & $3,95 a$ & 23,99 & 19,61 & 20,99a & 14,71 & $33,46 b$ \\
\hline & Serbest & 66 & 13,81 & $40,53 \pm 0,778^{a}$ & 30 & 62 & $8,22 \mathrm{ab}$ & 8,50 & $3,57 a b$ & 26,22 & 18,75 & 19,61ab & 15,13 & $34,95 a b$ \\
\hline \multirow{6}{*}{$\begin{array}{c}\text { Annesinin Öğrenim } \\
\text { Durumu }\end{array}$} & Okur Yazar Değil & 134 & 28,03 & $37,17 \pm 0,626 b$ & 25 & 62 & 8,63a & $9,64 a$ & 3,89 & 22,91 & $19,01 \mathrm{bc}$ & 20,79 & 15,12ab & $33,25 b$ \\
\hline & Okur Yazar & 49 & 10,25 & $38,63 \pm 0,752 \mathrm{ab}$ & 28 & 50 & 7,87ab & $6,61 \mathrm{~b}$ & 3,88 & 26,21 & $21,62 a$ & 20,12 & $13,68 b$ & $34,58 b$ \\
\hline & İlkokul & 110 & 23,01 & $38,35 \pm 0,611 \mathrm{ab}$ & 26 & 60 & $8,56 a$ & 7,59ab & 4,03 & 25,70 & $18,93 \mathrm{bc}$ & 20,86 & 14,33ab & $33,43 a b$ \\
\hline & Ortaokul & 78 & 16,32 & $38,87 \pm 0,792 \mathrm{ab}$ & 25 & 55 & 7,49ab & 7,95ab & 3,65 & 25,03 & $18,47 \mathrm{bc}$ & 21,57 & $15,83 a b$ & 36,02ab \\
\hline & Lise & 58 & 12,13 & $40,24 \pm 1,035 a$ & 28 & 58 & 8,02ab & $9,39 a$ & 3,55 & 25,53 & $17,77 \mathrm{c}$ & 19,56 & $16,17 a$ & $35,05 a b$ \\
\hline & Üniversite & 49 & 10,25 & $39,90 \pm 0,852 a$ & 30 & 62 & $6,99 b$ & 9,72a & 3,79 & 23,40 & 20,35ab & 19,64 & $16,12 a$ & $36,81 \mathrm{a}$ \\
\hline \multirow{3}{*}{ Annesinin Mesleği } & Ev Hanımı & 441 & 92,26 & $38,36 \pm 0,326$ & 25 & 62 & $8,16 a b$ & 8,43 & 3,84 & 24,65 & 19,16 & 20,61 & $15,14 a b$ & 34,28 \\
\hline & Memur & 24 & 5,02 & $40,38 \pm 1,329$ & 30 & 54 & $6,24 b$ & 10,37 & 3,51 & 24,47 & 19,22 & 19,63 & $16,56 a$ & 37,39 \\
\hline & İşçi & 13 & 2,72 & $40,54 \pm 1,992$ & 30 & 51 & $9,90 a$ & 9,46 & 4,10 & 23,38 & 18,84 & 21,91 & $12,40 \mathrm{~b}$ & 35,09 \\
\hline \multirow{2}{*}{$\begin{array}{l}\text { Babası Düzenli Para } \\
\text { Kazanıyor mu? }\end{array}$} & Evet & 369 & 77,20 & $38,47 \pm 0,358$ & 25 & 62 & 7,95 & 8,82 & $3,73 b$ & 24,74 & 18,91 & 20,45 & 15,41 & $35,08 a$ \\
\hline & Hayır & 109 & 22,80 & $38,71 \pm 0,649$ & 26 & 62 & 8,66 & 7,69 & $4,17 \mathrm{a}$ & 24,15 & 20,00 & 21,11 & 14,22 & $32,37 b$ \\
\hline \multirow{2}{*}{$\begin{array}{l}\text { Annesi Düzenli Para } \\
\text { Kazanıyor mu? }\end{array}$} & Evet & 58 & 12,13 & $39,14 \pm 0,862$ & 27 & 62 & 7,35 & $10,32 \mathrm{a}$ & 3,77 & 24,16 & 19,47 & 19,39 & 15,53 & $36,99 a$ \\
\hline & Hayır & 420 & 87,87 & $38,44 \pm 0,336$ & 25 & 62 & 8,21 & $8,32 b$ & 3,84 & 24,67 & 19,11 & 20,77 & 15,08 & $34,11 b$ \\
\hline \multirow{2}{*}{ Eviniz Kira mı? } & Evet & 159 & 33,26 & $37,80 \pm 0,560$ & 25 & 62 & 8,07 & 8,11 & 3,99 & $23,01 b$ & 19,55 & 21,35 & $15,92 a$ & 33,49 \\
\hline & Hayır & 319 & 66,74 & $38,88 \pm 0,376$ & 25 & 62 & 8,13 & 8,78 & 3,75 & $25,40 a$ & 18,96 & 20,22 & $14,75 b$ & 34,94 \\
\hline \multirow{2}{*}{ Otomobil var mı? } & Evet & 202 & 42,26 & $38,89 \pm 0,488$ & 25 & 62 & 7,77 & $9,40 \mathrm{a}$ & $3,65 b$ & 24,81 & 18,64 & 20,53 & 15,19 & 35,31 \\
\hline & Hayır & 276 & 57,74 & $38,25 \pm 0,408$ & 25 & 62 & 8,36 & $7,94 \mathrm{~b}$ & $3,96 a$ & 24,45 & 19,54 & 20,65 & 15,10 & 33,84 \\
\hline \multirow{3}{*}{$\begin{array}{l}\text { Hayvansal gidaların } \\
\text { besin değerlerini } \\
\text { biliyor musunuz? }\end{array}$} & Evet & 196 & 41,00 & $37,93 \pm 0,492$ & 25 & 62 & 7,99 & $9,05 a$ & 3,79 & 24,80 & 19,23 & $19,81 b$ & $15,32 a$ & $35,86 a$ \\
\hline & Hayır & 103 & 21,55 & $38,67 \pm 0,720$ & 25 & 60 & 8,36 & $8,94 a b$ & 3,74 & 24,19 & 18,86 & $21,77 a$ & $14,14 \mathrm{~b}$ & $34,17 a b$ \\
\hline & Kismen & 179 & 37,45 & $39,08 \pm 0,486$ & 25 & 55 & 8,09 & $7,80 \mathrm{~b}$ & 3,93 & 24,63 & 19,26 & 20,79ab & 15,51ab & $33,10 \mathrm{~b}$ \\
\hline
\end{tabular}




\section{Babaların Öğrenim Durumuna ve Mesleğine Göre Protein Tüketimleri}

Babanın öğrenim durumuna göre öğrencilerin günlük protein tüketimleri arasındaki farklılık önemsiz bulunurken, protein kaynağı olarak süt $(\mathrm{P}<0,01)$, yoğurt, tavuk ve kırmızı et tercihleri arasında istatistiki olarak önemli düzeyde farklılık bulunmuştur $(\mathrm{P}<0,05)$. Babanın öğrenim durumu ile çocukların kilosu arasında önemli düzeyde bir ilişki tespit edilmiştir $(\mathrm{P}<0,01)$ (Tablo 2). Babaları ilkokul mezunu olanlar hariç, babaların öğrenim durumu arttıkça öğrencilerin kilolarının da arttığı görülmüştür. Buna göre en yüksek protein tüketimi üniversite mezunu (36,43 g), en düşük ise ilkokul mezunu olan babaların çocuklarında $(33,06 \mathrm{~g})$ gerçekleşmiştir. Süt tüketimi en çok okuryazar olan babaların çocuklarında, yumurta tüketimi en çok okuryazar olmayan babaların çocuklarında, yoğurt ve balık tüketimi en çok ilkokul mezunu, peynir tüketimi en çok ortaokul, tavuk tüketimi en çok okuryazar olmayan, kırmızı et tüketimi ise en çok üniversite mezunu olan babaların çocuklarının tükettiği belirlenmiştir.

Ankete katılan çocukların baba mesleği olarak en çok işçilerin (272 kişi) yer aldığı belirlenmiştir. Babanın mesleğine göre öğrencilerin günlük protein tüketimi $(\mathrm{P}<0,05)$ ve kilosu $(\mathrm{P}<0,01)$ arasındaki farklılık istatistiki olarak önemli bulunmuş ve buna göre en yüksek protein tüketimi memur çocuklarında $(36,19 \mathrm{~g})$ görülürken, bunu çiftçi, serbest meslek ve işçi $(33,46 \mathrm{~g})$ çocukları şeklinde sıralandığı tespit edilmişstir. Babalarının mesleğine göre çocukların ağırlığı incelendiğinde, en düşük grubun işçi $(37,63 \mathrm{~kg})$, daha sonra memur, çiftçi ve serbest meslek şeklinde sıralandığı belirlenmiştir. Yoğurt ve tavuk eti bakımından meslek grupları arasında istatistiki olarak anlamlı bir fark görülmüştür $(\mathrm{P}<0,05)$. Babaları işçi ve memur olarak çalışan, sabit ücretli kesimin çocuklarının yoğurt ve tavuk etini daha çok tercih ettiği; süt, balık ve kırmızı et tüketenlerin çiftçi, peyniri daha çok tercih edenlerin ise serbest meslek grubu babaların çocuklarından olduğu tespit edilmiştir.

\section{Annelerin Öğrenim Durumu ve Mesleğine Göre Protein Tüketimleri}

Çocukların annelerinin öğrenim durumuna göre en büyük grubu 134 kişi ile okur-yazar olmayanlar oluşturmuştur. Bunları ilkokul mezunu olanlar (110 kişi) izlemiştir. Anneleri üniversite mezunu olan öğrenciler günlük protein tüketimi en yüksek $(36,81 \mathrm{~g})$ olan grup olmuştur. Annenin eğitim durumuna göre öğrencilerin protein tüketimleri arasında istatistiki olarak önemli düzeyde farklılık tespit edilmekle beraber $(\mathrm{P}<0,05)$; öğrencinin kilosu, protein kaynağ1 olarak yumurta, süt $(\mathrm{P}<0,01)$, balık ve kırmızı et tüketimleri arasında farklılık önemli bulunmuştur $(\mathrm{P}<0,05)$. En yüksek günlük protein tüketimi üniversite mezunu olan annelerin çocuklarında 36,81 g olarak belirlenirken, en düşük değeri anneleri okur-yazar olmayan grupla 33,25 g düzeyinde tespit edilmiştir. Yumurta tüketimi okur-yazar olmayan ve ilkokul mezunu annelerin, süt tüketimi en çok üniversite mezunu annelerin, yoğurt tüketimi ilkokul mezunu annelerin, peynir ve balık tüketenlerin okur-yazar annelerin, tavuk tüketenlerin ortaokul mezunu ve kırmızı et tüketenlerin ise lise mezunu annelerin çocuklarında saptanmıştır. (Tablo 2). Üniversite mezunu olan annelerin çocuklarının daha fazla süt, balık ve kırmızı 
et tüketmeleri göreceli olarak daha iyi yaşam koşullarına sahip olmalarıyla ve daha bilinçli olmalarına bağlanabilir.

Çocukların annelerinin mesleği olarak en büyük grubu 441 kişiyle ev hanımları olduğu ve bunların çocuklarının ortalama protein tüketiminin 34,28 g olarak düşük olduğu belirlenmiştir. Mesleği memur olan eğitimli annelerin çocukları daha fazla protein $(37,39 \mathrm{~g})$ tükettikleri görülmüştür. Annenin mesleği bakımından öğrencilerin yumurta $(\mathrm{P}<0,01)$ ve kırmızı et tüketimleri $(\mathrm{P}<0,05)$ arasında istatistiki olarak anlamlı bir farklılık saptanmıştır. Anneleri memur olan çocuklar daha fazla süt, balık ve kırmızı et tüketirken, işçi çocukları yumurta, yoğurt ve tavuk eti tüketmekte, peynir tüketenlerin daha çok ev hanımı annelerin çocukları olduğu belirlenmiştir.

Çalışmamızdan elde edilen annelerin mesleği ve öğrenim durumuyla ilgili sonuçlar, Taşdemir (2019)'in annelerin \%95,2'si ev hanımı; Bilgen Sivri ve Özpulat (2015)'ın Akşehir merkezdeki ilkokul öğrencilerinin anneleri için tespit ettikleri \%83,7'sinin ev hanımı ve \%71,6'sının ilkokul mezunu olduğunu belirten sonuçlarla benzer bulunmuştur.

\section{Babaların ve Annelerin Düzenli Para Kazanmasına göre Protein Tüketimleri}

Babaların düzenli para kazanmasına göre çocukların yoğurt ve günlük tüketilen protein miktarı arasında istatistiki olarak anlamlı bir farklı1ık söz konusudur $(\mathrm{P}<0,01)$. Babaları düzenli para kazanan öğrencilerin (369 kişi) kişi başı günlük protein tüketim miktarı 35,08 g iken, düzenli para kazanamayanlarda (109 kişi) bu miktar 32,37 g olarak tespit edilmiştir. Düzenli para kazanan babaların çocuklarının süt, peynir ve kırmızı eti daha çok tüketirken, düzenli para kazanamayan babaların çocuklarının ise yumurta, yoğurt, balık ve tavuk etini daha çok tercih ettikleri belirlenmiştir (Tablo 2).

Annelerin düzenli para kazanmasına göre çocukların günlük tüketilen protein miktarı bakımından istatistiki olarak önemli düzeyde farklılık söz konusudur $(\mathrm{P}<0,05)$. Annelerin \% 88 gibi büyük çoğunlukla düzenli para kazanmadıkları görülmüştür. Düzenli para kazanan annelerin çocuklarının protein tüketimi 36,99 g olarak gerçekleşirken, diğer grubun 34,11 g protein tükettikleri tespit edilmiştir. Düzenli para kazanan annelerin protein kaynağı olarak süt, balık ve kırmızı eti tercih ettiği, düzenli para kazanmayan annelerin yumurta, yoğurt, peynir ve tavuk eti tercih ettikleri belirlenmiştir (Tablo 2).

\section{Ailelerin İkamet Ettiği Evin Mülk veya Kira Olmasına Göre Protein Tüketimleri}

Ankete katılan öğrencilerden evi olan 319, kiracı olan 159 ailenin olduğu belirlenmiştir. Evi olanlarla olmayanlar arasında protein kaynağı olarak peynir ve kırmızı et tercihleri bakımından istatistiki olarak anlamlı bir farklılık görülürken $(\mathrm{P}<0,05)$, incelenen diğer parametreler arasındaki farkl1lık önemsiz bulunmuştur. Kiracı olan ailelerin çocukları $(33,49 \mathrm{~g})$ daha çok yoğurt, balık, tavuk ve kırmızı et tercih ettikleri, buna karşın evi olanların (34,94 g) yumurta, süt ve peyniri tercih ettiği belirlenmiştir (Tablo 2). Ailelerin maddi durumlarını yansıtan en önemli kriterlerden birisi olan oturulan evin mülkiyet 
durumudur. Buna göre kendi evlerinde oturanların maddi durumları kirada oturanlardan daha iyi olması ve dolayısı ile günlük protein tüketimlerinin daha yüksek olması beklenilen bir durumdur.

\section{Ailelerin Otomobil Varlığına Göre Protein Tüketimleri}

Yapılan anket çalışmasında ankete katılan öğrencilerden ailesinin otomobili olan 202 çocuğun ortalama protein tüketimi 35,31 g olarak gerçekleşirken, otomobili olmayan 276 çocuğun 33,84 g protein tükettiği saptanmıştır. Otomobili olanlarla olmayanlar arasında protein kaynağı olarak süt ve yoğurt tercihleri bakımından istatistiki olarak anlamlı bir farklılık görülmüştür $(\mathrm{P}<0,05)$. Otomobili olan öğrenci ailelerinin gelir durumlarının olmayanlara göre daha iyi olduğu düşünüldüğünde günlük protein tüketimi de daha yüksek olarak gerçekleşmiştir. Otomobili olan ailelerin çocukları süt, peynir ve kırmızı eti daha çok tercih ederken, otomobili olmayan ailelerin çocukları yumurta, yoğurt, balık ve tavuk etini daha çok tercih ettikleri görülmüştür (Tablo 2).

\section{Hayvansal Gıdaların Besin Değerlerinin Farkındalığına Göre Protein Tüketimi}

Hayvansal gıdaların besin değerini bildiklerini ifade eden 196 öğrencinin ortalama kilosu en düşük olarak (37,93 kg) gerçekleşirken, bilmediğini beyan eden 103 öğrencinin 38,67 kg ve kısmen bildiğini belirten 179 öğrencinin 39,08 kg olarak tespit edilmiştir. Günlük toplam protein tüketimleri ise en yüksek düzeyde 35,86 g ile besin değerini bilenlerde gerçekleşirken bunu, bilmeyenler $(34,17 \mathrm{~g})$ ve kısmen diyenler $(33,10 \mathrm{~g}$ ) izlemiştir (Tablo 2).

Hayvansal gıdaların besin değerlerini bilip, bilmedikleri grupları arasında protein kaynağı olarak süt, tavuk, kırmızı et ve günlük ortalama tüketilen protein oranı bakımından istatistiki olarak anlamlı bir farklılık görülmüştür $(\mathrm{P}<0,05)$. Hayvansal gıdaların besin değerlerini bildiklerini söyleyenler süt ve yoğurdu daha çok tercih ederken, bilmeyenler yumurta ve tavuk etini, kısmen bilenler ise yoğurt, balık ve kırmızı eti tercih etmişlerdir. Hayvansal protein kaynaklarının besin değerini bildiklerini ifade edenlerin düşük kilolu olmaları öğrencilerin bu konuda bilinçli olduklarını ve sağlıklı beslendiklerini göstermektedir.

\section{Sonuç}

Araştırma sonucuna göre; öğrencilerin cinsiyeti, yaşı, yaşadığı ilçe, sınıfı, kardeş sayısı, ailenin eğitim durumu ve ebeveynlerinin maddi durumu ile beslenme tercihleri tüketilen et, süt ve süt mamulleri ile yumurta tüketim arasında istatiksel bir ilişki olduğu saptanmıştır. Günümüzde ülkelerin en önemli gelişmişlik kriterlerinden olan kişi başına hayvansal protein tüketimi bakımından Diyarbakır merkezdeki ilköğretim öğrencilerinin yeterli ve dengeli beslendikleri söylenebilir. Okul çağındaki genç nesillerin sağlıklı ve dengeli beslenmesi geleceğin toplumunun inşası için önemlidir. Besin tercihlerinde gıda fiyatlarına ilave olarak ailenin gelir durumu ile tüketim alışkanlıkları belirleyici olmaktadır. Sağlıklı ve dengeli beslenme alışkanlıklarının büyüme ve gelişme dönemindeki çocuklara erken yaşlarda kazandırılması büyük önem taşımaktadır. Ankete katılan öğrencilerin önemli bir 
kısmının (103 kişi) hayvansal proteinlerin önemine dair yeterli bilgiye sahip olmadıkları tespit edilmiştir. Konu hakkında öğrencilere eğitim vermek için mevcut müfredatlara konunun eklenmesi, ayrıca ailelerinde bu konuda bilinçlendirilmesi yararlı olacaktır.

\section{Çıkar Çatışması Beyanı}

Makale yazarları herhangi bir çıkar çatışması olmadığını beyan ederler.

\section{Araştırmacı Katkı Oranı Beyan Özeti}

Yazarlar makaleye eşit oranda katkı sağlamış olduğunu beyan eder.

\section{Kaynakça}

Açıkgöz S. Üniversite öğrencilerinin beslenme alışkanlıkları ile özyetkinlik ve iyimserlik ilişkisi: Ankara Üniversitesi örneği. Ankara Üniversitesi. Yüksek Lisans Tezi (Yayınlanmamış) 2006. Ankara.117s. Tarihi: 12.05.2020).

Anonim. Social Sciences Research and Instructional Council Teaching Resources Depository 2018. SPSS for Windovs, Version, 24.0: A Brief Tutorial.

Anonim. http://www.bdb.hacettepe.edu.tr/TOBR_kitap.pdf (Erişim Tarihi: 28.11.2020). 2020a.

Anonim. https://dosyasb.saglik.gov.tr/Eklenti/10915,tuber-turkiye-beslenme-rehberipdf.pdf (Erişim Tarihi: 28.05.2020). 2020b.

Anonim. https://www.who.int/data/gho/data/themes/topics/topic-details/GHO/mean- body-massindex-trends-age-standardized-(kg-m-) (Erişim Tarihi: 28.05.2020). 2020c.

Baykan S. Ankara'nın farklı sosyo-ekonomik düzeylerinde 0-6 yaş çocuklarının gelişim durumlarının incelenmesi. Ankara: Milli Eğitim Basımevi 1999. 135s.

Baysal A. Kahvaltı ve okul başarısı. Beslenme ve Diyet Dergisi 1999; 28: 1-3.

Baysal A. Beslenme. Hatiboğlu Yayınları 2004; 144s. Ankara.

Bilgen Sivri B., Özpulat F. İlkokuldaki öğrencilerin beslenme alışkanlıkları ve annelerinin beslenmeye iliş̧in bilgi düzeyi. ACED. Uluslararası Aile Çocuk ve Eğitimi Dergisi 2015; 7: 20-30.

Du X., Zhu K., Trube A., Zhang Q., Ma G., Hu X., Fraser DR., Greenfield H. School-milk intervention trial enhances growth and bone mineral accretion in Chinese girls aged 10-12 years in Beijing. Br J Nutr 2004; 92: 159-168.

Duncan DB. Multiple Range and Multiple F Tests, Biometrics 1955; 11: 1- 42.

Garipağaoğlu M., Özgüneş N. Okullarda beslenme uygulamaları. Çocuk Dergisi 2008; 8(3): 152-159.

Gürer B. Türkiye’de hayvansal ürünlerde gıda güvencesinin analizi. Ç.Ü. Fen Bilimleri Enstitüsü, Doktora Tezi, (Yayınlanmamış) 2013; 191s. Adana. 
Karaca P., Pekyaman A., Güney H. Ebeveynlerin televizyon reklam içeriklerinin çocuklar üzerindeki etkilerini etik açıdan algılamalarına yönelik bir araştırma. Sosyal Bilimler Dergisi 2007; 9(2): 233 - 249.

Kaşıkçı S. Edirne ili merkez ilköğretim okullarında okuyan 6., 7. ve 8. sınıf öğrencilerinin beslenme alışkanlıkları üzerine bir araştırma. Namık Kemal Üniversitesi Fen Bilimleri Enstitüsü, Yüksek Lisans Tezi 2010.

Kılıç E., Şanlıer N. Üç kuşak kadının beslenme alışkanlıklarının karşılaştırılması. Kastamonu Eğitim Dergisi 2007; 15(1): 31 - 44.

Kutlu R., Çivi S. Özel bir ilköğretim okulu öğrencilerinde beslenme alışkanlıklarının ve beden kitle endekslerinin değerlendirilmesi. Fırat Tıp Dergisi 2009; 14(1): 18 - 24.

Nişancı Kılınç F., Çağdaş D. Sağlık meslek lisesi öğrencilerinin beslenme alışkanlıklarının, beslenme bilgi düzeylerinin ve vücut bileşimlerinin değerlendirilmesi. Türk Pediatri Arşivi Dergisi 2012; 47: 181-188.

Pekşen Akça R. Çocuk gelişimi ve eğitimi oyunlarla besleniyorum. Mungan Kavram Yayınları 2010. İzmir. $173 \mathrm{~s}$.

SPSS Inc. SPSS for Windows. Version 21.00 2021. Chicago.

Taşdemir A. İlköğretim öğrencilerinde beslenme eğitimi üzerine bir araştırma. Sağlık Akademisi Kastamonu 2019; 4(1): 34-52.

Törüner EK., Büyükgönenç L. Çocuk sağlığı temel hemşirelik yaklaşımları. Göktuğ Yayıncılık, 2. Bask1 2012; 680s. Ankara. 
Ek 1

Tablo 1. Anket Formu

\begin{tabular}{|c|c|c|c|c|c|c|}
\hline \multicolumn{7}{|l|}{ 1. Sinıfiniz? } \\
\hline \multicolumn{7}{|l|}{ 2. Yaşınız? } \\
\hline \multicolumn{7}{|l|}{ 3. Boyunuz kaç cm? } \\
\hline \multicolumn{7}{|l|}{ 4. Kilonuz kaç kg? } \\
\hline \multicolumn{7}{|l|}{ 5. Kardeș sayınız } \\
\hline \multicolumn{7}{|l|}{ 6. Babanızın öğrenim durumu? } \\
\hline \multicolumn{7}{|l|}{ 7. Babanızın mesleği? } \\
\hline \multicolumn{7}{|l|}{ 8. Annenizin öğrenim durumu? } \\
\hline \multicolumn{7}{|l|}{ 9. Annenizin mesleği? } \\
\hline \multicolumn{7}{|c|}{ 10. Babanız düzenli para kazanıyor mu? } \\
\hline \multicolumn{7}{|c|}{ 11. Anneniz düzenli para kazanıyor mu? } \\
\hline \multicolumn{7}{|l|}{ 12. Eviniz kira $\mathrm{m} 1$ ? } \\
\hline \multicolumn{7}{|l|}{ 13. Otomobiliniz var $\mathrm{m}$ ? } \\
\hline \multicolumn{7}{|l|}{ 14. Okul harçlığı alıyor musunuz? } \\
\hline \multicolumn{7}{|l|}{ 15. Günlük harçlığınız kaç TL? } \\
\hline \multicolumn{3}{|c|}{ 16. Ailenizde hayvancıllk ile uğraşan biri var mı? } & A) Evet & & B) Hayır & \\
\hline \multicolumn{4}{|c|}{ 17. Hayvansal gidaların besin değerlerini biliyor musunuz? } & A) Evet & B) Hayır & C)Kısmen \\
\hline \multicolumn{3}{|c|}{ 18. Hayvansal ürünler bize ne fayda sağlar? } & \multicolumn{2}{|c|}{ A) Kemikleri geliştirir } & \multicolumn{2}{|c|}{ B) Vitamin sağlar } \\
\hline \multicolumn{3}{|c|}{ C) Büyüme ve zekamızı } & \multicolumn{2}{|c|}{ D) Boyumuzu uzatır } & \multicolumn{2}{|c|}{ E) Hepsini } \\
\hline 19. Bir haftada kaç adet yumurta & A) 0 & & B) $1-3$ & C) $4-5$ & D) 6-7 & E) $>8$ \\
\hline 20. Bir günde kaç bardak süt & A) 0 & & B) 1 & C) 2 & D) 3 & E) $>4$ \\
\hline \multicolumn{3}{|c|}{ 21. Bir haftada kaç gün süt içersiniz? } & A) 0 & B) $1-3$ & C) 4-5 & D) 6-7 \\
\hline \multicolumn{3}{|c|}{ 22. Bir haftada kaç gün yoğurt tüketirsiniz? } & A) 0 & B) $1-3$ & C) $4-5$ & D) 6-7 \\
\hline \multicolumn{3}{|c|}{ 23. Bir haftada kaç gün peynir tüketirsiniz? } & A) 0 & B) $1-3$ & C) $4-5$ & D) 6-7 \\
\hline 24. Hangi peyniri tercih & A) Kaşar & & Beyaz & \begin{tabular}{l|l} 
C) Örgü & D) C \\
\end{tabular} & E) Hepsi & \begin{tabular}{l|l} 
& F) Hiçbiri \\
\end{tabular} \\
\hline 25. Bir ayda kaç kere balık & A) 0 & & B) $1-3$ & C) $4-5$ & D) 6-7 & A) $>8$ \\
\hline 26. Bir haftada kaç gün tavuk eti & A) 0 & & B) $1-2$ & C) $3-4$ & D) 5-6 & A) 7 \\
\hline 27. Bir haftada kaç gün kırmızı et & A) 0 & & B) $1-2$ & C) 3-4 & D) 5-6 & A) 7 \\
\hline 28. Sizce en sağlıkl1 ve besleyici et & A) Kuzl & & B) Dana & C) Tavuk & D) Balık & E) Hepsi \\
\hline 29. Sizce süt ve yumurta tüketimi & A) 0 & & B) $1-3$ & C) $4-5$ & D) 6-7 & A) $>8$ \\
\hline
\end{tabular}

